\title{
THE POTENTIAL FOR FOREIGN INVESTMENT IN A DOMESTIC CREDIT RATING AGENCY IN VIET NAM
}

Surinder D. Kathpalia, Chu Hong Minh, Do Thuy Huong, and Don J. Lambert

NO. 19

September 2020

\section{ADB SOUTHEAST ASIA WORKING PAPER SERIES}





\section{ADB Southeast Asia Working Paper Series}

\section{The Potential for Foreign Investment in a Domestic Credit Rating Agency in Viet Nam}

Surinder D. Kathpalia, Chu Hong Minh, Do Thuy Huong, and Don J. Lambert

No. 19 | September 2020
Surinder D. Kathpalia co-founded Standard \& Poor's Singapore office in 1996 and helped build S\&P's regional network through a series of management positions, including Head of its Singapore, Kuala Lumpur, and Hong Kong, China offices. At the end of 2014 he retired from S\&P as managing director of ASEAN and South Asia. Do Thuy Huong is a project analyst and Chu Hong Minh a senior financial sector officer in the Private Sector Development Unit of ADB's Viet Nam Resident Mission. Don Lambert leads the unit. The unit's work focuses on promoting the role of the private sector in Viet Nam's economic development. 
(C) 2020 Asian Development Bank 6 ADB Avenue, Mandaluyong City, 1550 Metro Manila, Philippines

Tel +632 8632 4444; Fax +63286362444

www.adb.org

Some rights reserved. Published in 2020.

Printed in the Philippines

Publication Stock No. WPS200262-2

DOI: http://dx.doi.org/10.22617/WPS200262-2

The views expressed in this publication are those of the authors and do not necessarily reflect the views and policies of the Asian Development Bank (ADB) or its Board of Governors or the governments they represent.

ADB does not guarantee the accuracy of the data included in this publication and accepts no responsibility for any consequence of their use. The mention of specific companies or products of manufacturers does not imply that they are endorsed or recommended by ADB in preference to others of a similar nature that are not mentioned.

By making any designation of or reference to a particular territory or geographic area, or by using the term "country" in this document, $A D B$ does not intend to make any judgments as to the legal or other status of any territory or area.

This work is available under the Creative Commons Attribution 3.0 IGO license (CC BY 3.0 IGO)

https://creativecommons.org/licenses/by/3.0/igo/. By using the content of this publication, you agree to be bound by the terms of this license. For attribution, translations, adaptations, and permissions, please read the provisions and terms of use at https://www.adb.org/terms-use\#openaccess.

This CC license does not apply to non-ADB copyright materials in this publication. If the material is attributed to another source, please contact the copyright owner or publisher of that source for permission to reproduce it. $\mathrm{ADB}$ cannot be held liable for any claims that arise as a result of your use of the material.

Please contact pubsmarketing@adb.org if you have questions or comments with respect to content, or if you wish to obtain copyright permission for your intended use that does not fall within these terms, or for permission to use the ADB logo.

The ADB Southeast Asia Working Paper Series presents data, information, and/or findings from ongoing research and studies to encourage exchange of ideas and elicit comment and feedback about development issues in Asia and the Pacific. Since papers in this series are intended for quick and easy dissemination, the content may or may not be fully edited and may later be modified for final publication.

Corrigenda to ADB publications may be found at http://www.adb.org/publications/corrigenda.

Notes:

In this publication, "\$” refers to United States dollars.

ADB recognizes "Hanoi" as Ha Noi and "Saigon" as Ho Chi Minh City. 
Australian

Aid

The authors gratefully acknowledge the Australian Department of Foreign Affairs and Trade for financing this research. The support of the State Bank of Viet Nam, Ministry of Finance, and the Viet Nam Bond Market Association is also highly appreciated. 



\section{CONTENTS}

TABLES AND FIGURES

ABBREVIATIONS vii

ABSTRACT

$\begin{array}{lll}\text { I. INTRODUCTION } & 1\end{array}$

A. Audience and Report Structure $\quad 1$

B. Report Conclusions 1

$\begin{array}{lll}\text { II. } & \text { VIET NAM'S ECONOMY } & 1\end{array}$

$\begin{array}{ll}\text { III. } & 4\end{array}$

A. Regulatory Bodies $\quad 4$

B. Bond Market Regulation 4

C. Credit Ratings Regulation 6

D. Conclusion 6

$\begin{array}{lll}\text { IV. } & \text { VIET NAM'S BOND MARKET } & 7\end{array}$

A. Evolution of Market $\quad 7$

B. Road Map for Bond Market 8

C. ASEAN Comparisons 9

D. Market Structure $\quad 11$

E. Intermediaries $\quad 12$

F. Investors 12

G. Governance and Transparency 13

H. Credit Culture 14

I. Bond Market Outlook 14

$\begin{array}{ll}\text { V. DOMESTIC CREDIT RATINGS } & 14\end{array}$

$\begin{array}{ll}\text { A. Background } & 14\end{array}$

B. Domestic Rating Agencies $\quad 15$

C. Global Rating Agencies $\quad 15$

D. Key Success Factors 16

E. Analytical Independence 16

F. Development Priority 16

G. Demand for Ratings 16

APPENDIXES

1. Viet Nam Bond Issuance and Asean Domestic Corporate Bonds 21 Issuance and Outstanding

2. Report Contributors 


\section{TABLES AND FIGURES}

\section{TABLES}

1 Viet Nam Bond Issuance $\quad 7$

2 ASEAN Domestic Ratings Overview 17

3 Potential Domestic Credit Rating Universe 18

\section{FIGURES}

1 Nominal Gross Domestic Product 2

2 Nominal Gross Domestic Product Growth Rate 2

3 Population $2019 \quad 3$

4 Aggregate Sources of Funding for Viet Nam's Corporates 8

5 Viet Nam Bonds Outstanding $\quad 9$

6 ASEAN Corporate Bonds Outstanding 9

7 ASEAN Domestic Corporate Bond Issuance 10

8 ASEAN Corporate Bonds Outstanding 10

9 Corporate Bonds $2019 \quad 17$ 


\section{ABBREVIATIONS}

$\begin{array}{ll}\text { ADB } & \text { Asian Development Bank } \\ \text { ASEAN } & \text { Association of Southeast Asian Nations } \\ \text { D } & \text { dong } \\ \text { GDP } & \text { gross domestic product } \\ \text { MARC } & \text { Malaysian Rating Corporation Berhad } \\ \text { PRC } & \text { People's Republic of China } \\ \text { RAM Group } & \text { RAM Holdings Berhad } \\ \text { S\&P } & \text { S\&P Global Ratings } \\ \text { SMEs } & \text { small- and medium-sized enterprises } \\ \text { Saigon Phatthinh } & \text { Saigon Phatthinh Rating Joint Stock Company } \\ \text { TRIS } & \text { TRIS Corporation Ltd. } \\ \text { US } & \text { United States } \\ \text { VBMA } & \text { Viet Nam Bond Market Association }\end{array}$




\section{ABSTRACT}

The Asian Development Bank commissioned this report to evaluate the attractiveness of the Viet Nam bond market from a global credit rating agency's perspective. It is intended to help a global credit rating agency to consider a market entry, ideally in cooperation with other market participants. It is not intended to be a report card for the bond market.

Viet Nam is the Association of Southeast Asian Nations' (ASEAN) sixth largest economy and the region's fastest growing economy. The United States-People's Republic of China (PRC) trade war over the past 18 months has accelerated the shift of manufacturing activity from the PRC to Viet Nam. Relative to other Asian countries, Viet Nam has been the least impacted by the coronavirus disease. Despite the expected short-term decline in economic growth in 2020, the economy of Viet Nam is expected to return to its growth trajectory in 2021 and stay on this path as the region's fastest growing economy.

The Viet Nam corporate bond market has grown rapidly since 2017 and issuances of $\$ 12.8$ billion in 2019 were larger than those for Indonesia and the Philippines. Private placements accounted for $94 \%$ of corporate bond issuances in 2018 and 2019 following easing of disclosure requirements and issuance conditions. However, the lack of a credit culture poses significant risks to the bond market and the financial sector, particularly as individual investors currently own almost a fourth of all bond issues.

Lack of demand for credit ratings in the past has been the limiting factor for a domestic credit rating agency in Viet Nam. Two domestic rating agencies have been licensed by the Ministry of Finance (the first in 2017 and the second in March 2020). They are yet to become operational. The recently passed 2019 Securities Law requires some public bond issues (but not private placements) to be rated by a domestic rating agency effective January 2021. Further, draft regulations that guide the implementation of the new Securities Law require few, if any, bond issues to be rated unlike other ASEAN markets that mandated credit ratings for public - and often private-offerings during their formative years.

Viet Nam's policy makers are keen to see an orderly growth of a healthy bond market and have expressed a strong commitment for a domestic credit rating agency. The growth in the corporate bond market since 2017 is sustainable and the business case for a global rating agency to enter the Vietnamese market through a technical service agreement is compelling. A technical service agreement would provide a low-risk entry.

The country's market participants would prefer to see a collaboration of local institutions with a global rating agency. This would lead to an ideal blend of global best practices with a local understanding of culture, businesses, and practices. Further, technical cooperation between a global rating agency and a domestic rating agency will elevate the credibility of the domestic rating agency (through the reputation of the global rating agency for its analytical rigor and governance processes) and lead to greater market acceptance and usage of the domestic rating agency's ratings.

The more these bonds are rated-either through changes in the credit culture or regulations - the clearer the case will be for an international rating agency to go beyond a technical agreement and invest equity in either one of the established or a new domestic credit rating agency. 


\section{INTRODUCTION}

\section{A. Audience and Report Structure}

1. The objective of this report is to assess the attractiveness - from the vantage of a foreign entityof investing in a Vietnamese domestic credit rating agency. Such an investment could be through a (i) technical assistance agreement, (ii) minority equity interest, (iii) majority equity interest, or (iv) wholly owned subsidiary.

2. To understand the merits of these options, the second chapter provides an overview of the economy of Viet Nam and its growth potential. The third chapter provides a background of the regulatory environment for bonds and credit rating agencies, and the fourth chapter documents the bond market's growth-particularly since 2016.

\section{B. Report Conclusions}

3. The final chapter then assesses the feasibility of a foreign entity investing in a Vietnamese rating agency. It concludes that the business case for an international rating agency to enter the Vietnamese market through a technical service agreement is compelling. There are few in any markets with both (i) similarly strong fundamentals, and (ii) no international rating agency present. A technical service agreement would provide a low-risk entry.

4. Viet Nam already issues more corporate debt than countries such as Indonesia and the Philippines. The more these bonds are rated-either through changes in the credit culture or regulations - the clearer the case will be for an international rating agency to go beyond a technical agreement and invest equity in either one of the established or a new domestic credit rating agency.

\section{VIET NAM'S ECONOMY}

5. Viet Nam is the sixth largest economy of the Association of Southeast Asian Nations (ASEAN) and the region's fastest growing economy. At the end of 2019, Viet Nam's economy was approximately two-thirds the size of the Philippines, ASEAN's fifth largest economy (Figure 1). Viet Nam's nominal gross domestic product (GDP) at the end of 2019 was approximately $\$ 262$ billion ( $\$ 156$ billion in 2012). 
Figure 1: Nominal Gross Domestic Product

(\$ billion)

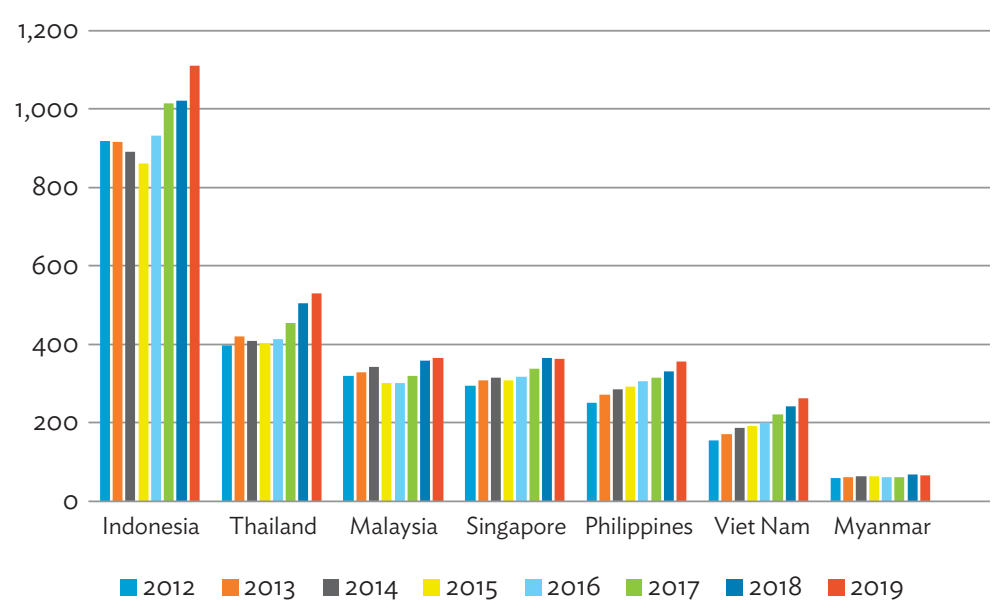

Source: International Monetary Fund.

6. Agriculture accounts for $14 \%$ of Viet Nam's GDP (17.6\% in 2012), industry $34.5 \%$ (33.2\% in 2012), and services $41.6 \%$ (37.9\% in 2012). The change in its economy's structure is reflected in greater urbanization, with the proportion of population residing in towns and cities growing to over $36 \%$ in 2019 from $31.6 \%$ in 2012.

Figure 2: Nominal Gross Domestic Product Growth Rate

$(\%)$

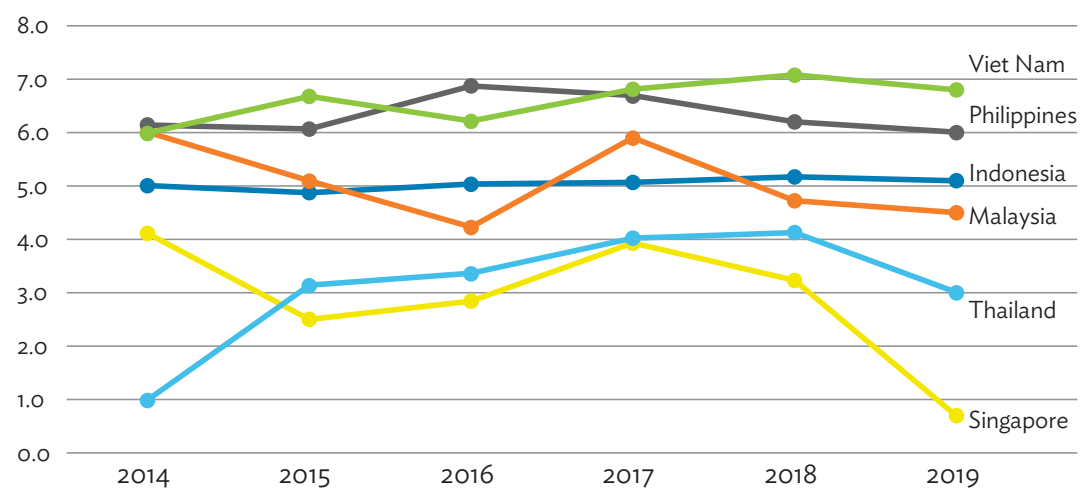

Source: Asian Development Bank.

7. Viet Nam's annual GDP growth, until the coronavirus disease (COVID-19) crisis, has consistently been over $6 \%$ since 2014, well above that of its ASEAN peers (Figure 2). The economy of Viet Nam has been stable during this period too, largely because it has been built on the back of an industrialization wave supported by foreign direct investment. At the same time, limited offshore portfolio investment has insulated Viet Nam from external financial shocks.

8. At the end of 2019, Viet Nam's population of 96.5 million was the third largest among ASEAN member states (Figure 3). Indonesia at 267 million and the Philippines at 108 million have larger populations than Viet Nam. Viet Nam's hardworking workforce has been a key pillar of Viet Nam's growth 
Figure 3: Population 2019

(Million)

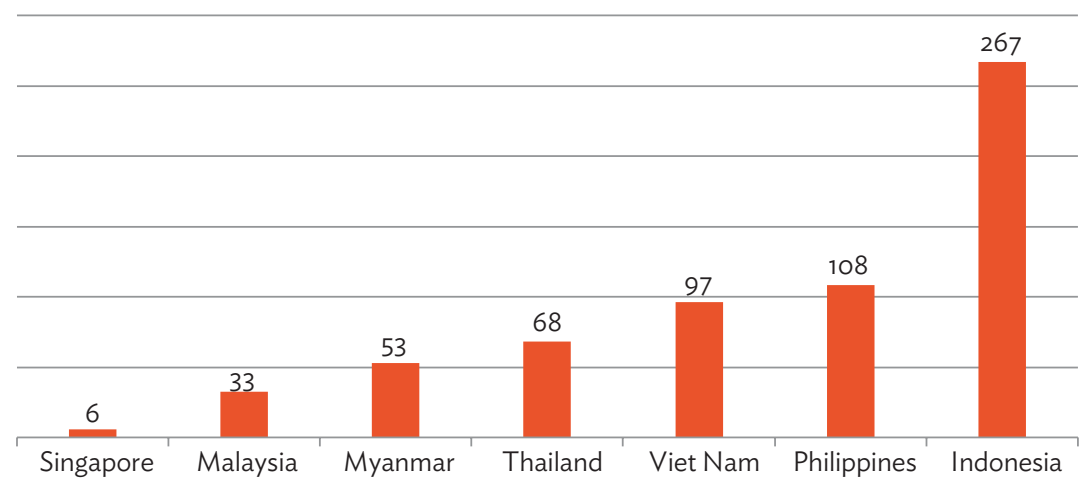

Source: International Monetary Fund.

story. Unemployment has hovered around 2\% since 2012 and its labor force participation rate remained around $77 \%$ during this period.

9. Annual foreign direct investment flows grew to $\$ 20$ billion in 2019 from $\$ 12$ billion in 2012, reflecting the growing attractiveness of Viet Nam as a manufacturing hub and a sizeable consumer market. Average household consumption grew $7 \%$ per annum during this period.

10. During 2019 and into 2020, the trade war between the United States (US) and the People's Republic of China (PRC) accelerated the shift of manufacturing activity from the PRC to Viet Nam and other ASEAN member states. Domestic consumption, driven by higher employment and a growing middle-class population, has supported the strong growth of Viet Nam's economy during this period.

11. As of 30 June 2020, Viet Nam had fewer cases of the COVID-19 disease than most ASEAN member states. Viet Nam's GDP grew by $3.8 \%$ year-on-year in the first quarter of 2020, the slowest GDP growth rate since 2009. The COVID-19 pandemic and weaker global demand for its products largely accounted for the slowdown. As of June 2020, full year growth for 2020 is expected to reduce to $4.1 \%$.

12. The US, European Union, and the PRC are Viet Nam's top three export markets accounting for more than half of the country's total exports as of end 2019. Viet Nam's largest imports come from Japan, the PRC, and the Republic of Korea. Over 59\% of imports come from these three countries, which were badly hit by the COVID-19 pandemic in early 2020 but had somewhat rebounded by midyear 2020.

13. Viet Nam's export-led growth, through being a major manufacturing center for the world, is expected to continue in the near future. The COVID-19 impact should lead to a further diversification of supply chains away from the PRC. Viet Nam's tourism, hospitality, and the banking sector will however be vulnerable to external shocks.

14. Viet Nam is expected to withstand the current 2020 economic crisis as it is much stronger now than during the last domestic downturn in 2010. Despite the expected short-term dip in economic growth in 2020, the economy of Viet Nam is expected to return to its growth trajectory by 2021 and stay on this path as the region's fastest growing economy.

\footnotetext{
ADB. 2020. Asian Development Outlook Supplement. Manila.
} 
15. Viet Nam's political, economic, and financial stability over much of the last decade have created a conducive environment for capital markets and the development of its corporate bond market.

\section{REGULATORY ENVIRONMENT}

\section{A. Regulatory Bodies}

16. Viet Nam has three regulatory organizations that oversee its bond market:

(i) Ministry of Finance. It has oversight of the securities market and is charged with policy and framework development for the capital markets. It also oversees the State Securities Commission (SSC).

(ii) State Bank of Viet Nam. It is the central bank of Viet Nam and formulates and implements the country's monetary policy. It also regulates the offering of debt instruments by credit institutions.

(iii) State Securities Commission. It implements the regulations governing the securities market and is also tasked with providing direction to the development of the securities market.

\section{B. Bond Market Regulation}

17. Securities regulations set out a legal framework for issuance of corporate bonds in Viet Nam. The existing 2006 Securities Law (as amended) will be superseded by the 2019 Securities Law with effect from 1 January 2021.

18. Corporate bonds can be issued by way of public or private offering. As a general rule, issuance of any bonds to more than 99 or an indefinite number of investors (excluding qualified professional investors such as credit institutions, securities firms, or insurance companies, etc.) would constitute a public offering. Any bond issuance that does not satisfy these criteria will be considered a private offering.

19. Public offerings of bonds are governed by Decree \#58 of July 2012, which guides the implementation of the Securities Law (as amended) and its explanatory circulars. A public debt offering requires a registration filing with the SSC and extensive disclosures by the issuer. The approval process can take up to 30 days (or up to 2 months in extraordinary cases). To issue bonds by way of public offering, an issuer would need to meet certain eligibility requirements. For example, the issuer needs to have a minimum paid-up share capital of D10 billion (about $\$ 430,000$ ); its business operation in the preceding year is profitable, etc.

20. Regulations for the private offerings of corporate bonds are outlined in Decree \#163 of December 2018. The Ministry of Finance has the prime responsibility for the implementation of this decree. It replaced Decree \#90 of October 2011, which previously guided the market.

21. Several conditions need to be met by issuers prior to private offering of bonds. Bond issuers need to have audited financial statements for the past financial year, board of directors' approval of the proposed bond issue, and a 3-year history of no defaults on principal or interest on past bond issues. Decree \#163 streamlined the issuance process and dropped a number of conditions in the older Decree \#90 such as minimum capital and profit track record in the case of private placements. 
However, privately placed bonds must be traded among no more than 99 investors (except for qualified professional investors). This restriction is lifted after a period of 1 year commencing from the issue date.

22. Private placements of bonds are not subject to pre-approval by any regulator, except for issuance of equity-linked bonds by a public company (requiring the SSC's approval) and issuance of corporate bonds by a state-owned enterprise (requiring approval from its sponsor authority in some cases). Such placements need to be reported to the Hanoi Stock Exchange within 5 business days of issuance and registered with the Viet Nam Securities Depository within 10 business days of issuance. Issuers make limited disclosures in a simple offering document and the issue is placed with less than 100 investors, excluding qualified professional investors. Documents are filed only in Vietnamese and pose challenges for non-native investment professionals.

23. Offshore bond issuances by Vietnamese entities need to pre-approved by the State Bank of Viet Nam. If the issuer is an insurance company, securities, or fund management company, additional approval from the Ministry of Finance or the SSC would be required.

24. Under the 2019 Securities Law, effective January 2021, some issuers of public bonds will require a credit rating. In June 2020, the Ministry of Finance issued a draft decree providing further guidance on this requirement. These are issuers whose

(i) total bond issuance value in the last 12 months is greater than $100 \%$ of equity, based on the latest annual audited financial statements; and

(ii) total bonds outstanding as of the registration of public bond issuance is greater than $200 \%$ of the equity, based on the latest annual audited financial statements.

25. However, privately placed bonds are not part of this mandatory requirement.

26. The Hanoi Stock Exchange has been designated by the government for the listing of corporate bonds. The exchange is required to disclose issuances on its website.

27. In July 2020, the government issued Decree No \#81 amending Decree \#163, effective from 1 September 2020, with several cooling measures for privately placed corporate bond issues. These cooling measures, which place limits on private placement issues, seek to shift issuance activity from the private placement market to public offerings of bonds. While reiterating a restriction set forth in Decree \#163 that bonds privately placed will only be tradable between no more than 99 investors (except for qualified professional investors) for a lock-up period of 1 year, Decree \#81 makes it clear that such a restriction does not apply to corporate bonds issued by Vietnamese issuers in Eurobond markets. In addition, Decree \#81 has increased the limit of bond issuance by noncredit institutions to a maximum of five times of issuer's equity, based on the latest quarterly audited financial statements, while maintaining the requirement for issuance intervals of 6 months.

28. Purchases of bonds by banks are subject to single customer limits as imposed by the State Bank of Viet Nam. Banks are also required to report purchases of bonds in their submissions to the State Bank of Viet Nam.

29. Viet Nam's Social Security, the country's main pension provider, is permitted to invest in bonds issued by banks. Both public and private pension funds are permitted to invest in government-guaranteed bonds. However, pension funds, whether public or private, are currently not permitted to invest in bonds of nonbank corporates. Currently, there are two licensed private pension funds in Viet Nam but they have not yet commenced operation. 
30. There is no regulation at present that prescribes the minimum rating categories for investments in bonds by insurance companies or pension funds. Decree \#81 is expected to be temporary. The authorities are drafting a new decree that will replace Decree \#163 and Decree \#81 and guide implementation of 2019 Securities Law in 2021. This new draft decree provides, among others, certain salient features as follows:

(i) Privately placed bonds will only be issued to qualified professional investors and strategic investors.

(ii) Privately placed bonds will only be tradable between qualified professional investors, except for convertible bonds and bonds with warrants, which will be tradable between qualified professional investors and strategic investors.

(iii) There is no limit to bond issuances, except for bond issuances by state-owned enterprises.

31 The draft decree is expected to be issued before end-2020 so that it would become effective from January 2021.

\section{Credit Ratings Regulation}

32. In September 2014, the Government of Viet Nam issued Decree \#88 for the licensing and operation of domestic credit rating agencies. This regulation is largely based on International Organization of Securities Commissions principles.

33. The Ministry of Finance is the regulator for credit rating activities in Viet Nam. It has the authority to grant up to five credit rating licenses by 2030.

34. Key requirements under Decree \#88 include the following:

(i) Foreign ownership up to $100 \%$ is permitted in a Vietnamese credit rating agency.

(ii) The requirement to engage 10 analysts, with at least 3 years' experience, could be met through analysts based in Viet Nam or overseas.

(iii) The chief executive officer of the rating agency is required to be based in Viet Nam and should have a degree and at least 10 years of relevant working experience.

(iv) The agency must have a Credit Rating Council of at least five members, each of whom shall have a relevant degree and at least 7 years relevant experience.

(v) The agency is required to submit to the Ministry of Finance its annually audited financial statements and related information on its operations in a prescribed format by 30 April of each year.

35. No tax incentives or subsidies are permitted under current regulations for rating agencies.

\section{Conclusion}

36. Although Viet Nam's regulations do not mandate ratings as widely as in India; Indonesia; the Philippines; the PRC; Taipei,China; Thailand; and until recently Malaysia, they do in other respects provide an adequate foundation for the development of the bond market and the establishment and operations of a credit rating agency. These issues are further discussed in Chapters 4 and 5. 


\section{VIET NAM'S BOND MARKET}

\section{A. Evolution of Market}

37. Viet Nam's bond market has evolved over the past 20 years. A steady pace of market reforms supported by a growing need of issuers for funding have led to annual bond issuance growing from D1.3 trillion ( $\$ 92$ million) in 2000 to D545 trillion ( $\$ 24$ billion) in 2019. Total bond issuances more than doubled between 2012 and 2019 growing from D228 trillion (\$11 billion) in 2012 to D545 trillion ( $\$ 24$ billion) in 2019 (Table 1). While government bond issues grew 63\% between 2012 and 2019, corporate bond issuance, including private placements, grew tenfold. However, government-guaranteed issues declined by $67 \%$ and municipal issues declined by $79 \%$ during this period.

Table 1: Viet Nam Bond Issuance

(D trillion)

\begin{tabular}{|c|c|c|c|c|c|}
\hline Year & Government & Guaranteed & Municipal & Corporate & Total \\
\hline 2012 & 141.3 & 52.6 & 4.8 & 28.7 & 227.5 \\
\hline 2013 & 181.1 & 47.4 & 8.5 & 34.4 & 271.3 \\
\hline 2014 & 248.0 & 27.7 & 7.1 & 48.0 & 330.9 \\
\hline 2015 & 256.2 & 47.9 & 7.5 & 42.8 & 354.4 \\
\hline 2016 & 312.2 & 34.5 & 3.5 & 97.4 & 447.6 \\
\hline 2017 & 244.2 & 34.4 & 2.2 & 115.4 & 396.2 \\
\hline 2018 & 221.0 & 26.2 & 0.8 & 238.4 & 486.3 \\
\hline 2019 & 229.8 & 17.5 & 1.0 & 296.7 & 544.9 \\
\hline
\end{tabular}

Refer to Table A1.1 in Appendix 1 for US\$ equivalents.

Source: Techcombank Securities and Viet Nam Bond Market Association.

38. Viet Nam's bond market comprises four components:

(i) Government bonds-issued by the government through the Ministry of Finance and largely for financing budget deficits. The government has been a frequent issuer and has helped the establishment of a yield curve across a range of medium- to long-term tenors.

(ii) Government guaranteed bonds-issued by state-owned policy banks or state-owned enterprises to finance state policy-targeted credit schemes or investment projects of importance to the country. These were popular until 2016 but have declined since then. As Viet Nam's government has significant long-term borrowings of its own, it has been less inclined to provide guarantees for fresh borrowings by state-owned companies.

(iii) Municipal bonds-issued by provinces and municipalities to fund their own budgets.

(vi) Corporate bonds-issued by banks and nonbank corporate issuers. As mentioned, these have grown significantly since 2012, with annual issuance doubling initially in 2016, and then again in 2018. It grew a further $24 \%$ in 2019. The slow growth prior to 2016 is attributed by some to impediments to corporate bond issuance in Decree \#90 of 2011.

39. The focus in the remainder of this chapter will be on Viet Nam's corporate bond market, which is a key factor for both determining the viability of a domestic credit rating agency and the factors a global credit rating agency would consider in deciding to enter the market. 


\section{B. Road Map for Bond Market}

40. For over 15 years Viet Nam's Ministry of Finance has promoted the development of the corporate bond market as an important step in the mobilization of capital for the economy. The country needed to reduce its reliance on the banking sector for funding its growth while tapping sizable domestic savings that ranged between $25 \%$ and $30 \%$ of GDP from 2000 to $2019 .{ }^{2}$

41. The government's Roadmap for Developing the Bond Market 2017-2020, published in August 2017, established objectives and milestones for the bond market. It enabled the government to introduce significant changes for reforming the bond market. While these reforms facilitated issuance and disintermediation, they also sought to increase investor protection through disclosures and related safeguards. ${ }^{3}$

\section{Figure 4: Aggregate Sources of Funding for Viet Nam's Corporates}

(\% of GDP)

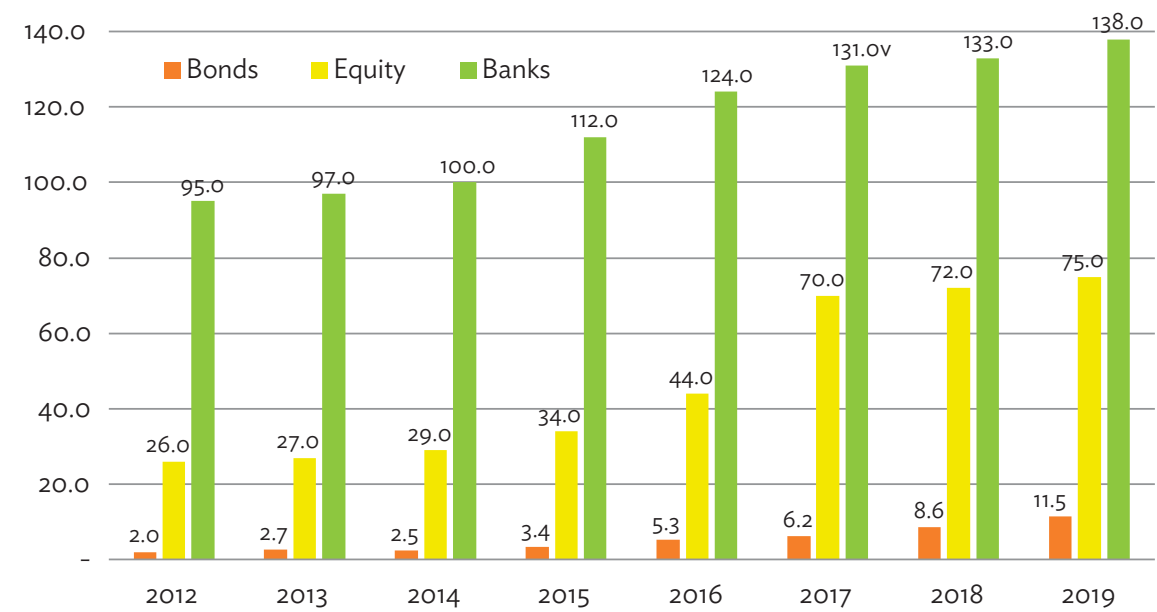

GDP = gross domestic product.

Source: Techcombank Securities and Viet Nam Bond Market Association.

42. Vietnamese corporates have historically funded their business expansion and new projects via the banking sector. This was supplemented by foreign direct investment. Equity markets became a more significant contributor post-2016. Although corporate bonds have grown rapidly since 2017, their contribution to corporate finance remains a fraction of bank credit and equities (Figure 4).

43. The road map of 2017 set a target for corporate bonds at $7 \%$ of GDP by 2020 , and $20 \%$ by 2030. By the end of 2019, the corporate bond market has exceeded the target for 2020 . The reforms introduced in 2018 (Decree \#163) enabled issuers to place corporate bonds privately with minimal requirements. As a consequence, corporate bonds outstanding grew to 11.5\% of GDP in 2019 (Figure 5).

2 ADB. 2019. Viet Nam Key Indicators. Manila. https://data.adb.org/dataset/viet-nam-key-indicators.

3 Government of the Socialist Republic of Viet Nam. Roadmap for Developing the Bond Market 2017-2020. Ha Noi. 
Figure 5: Viet Nam Bonds Outstanding

(\% of GDP)

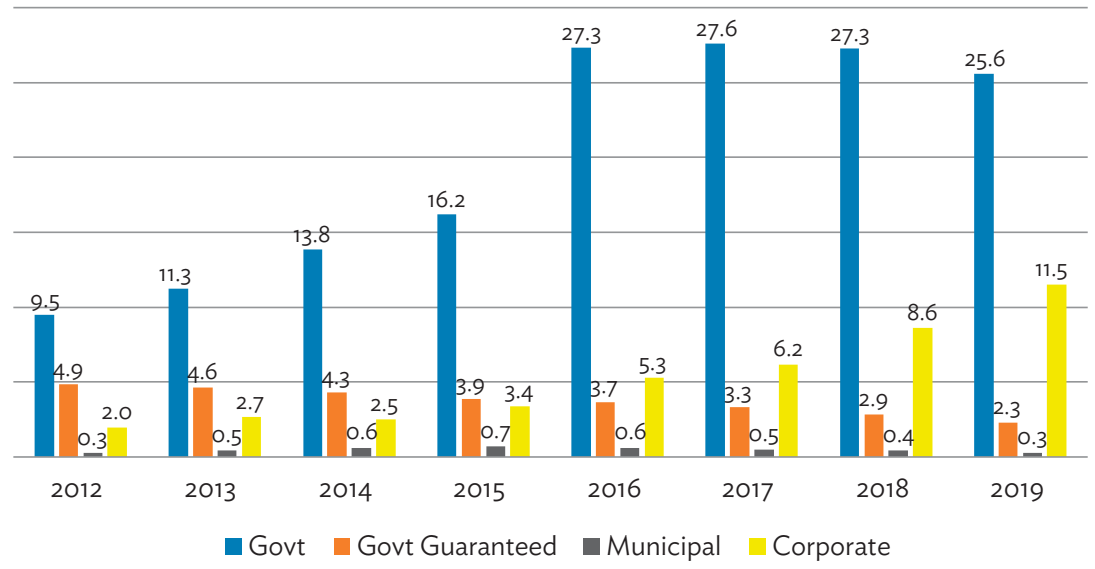

GDP = gross domestic product, Gov't. = government.

Source: Techcombank Securities and Viet Nam Bond Market Association.

\section{ASEAN Comparisons}

44. Corporate bonds outstanding as a proportion to GDP in Malaysia, Singapore, and Thailand are larger than that of Viet Nam. Viet Nam is ahead of the Philippines and Indonesia (Figure 6). Viet Nam's strong growth rate would suggest that it has the capacity to further grow the corporate bond market in line with targets established in the road map.

\section{Figure 6: ASEAN Corporate Bonds Outstanding}

(\% of GDP)

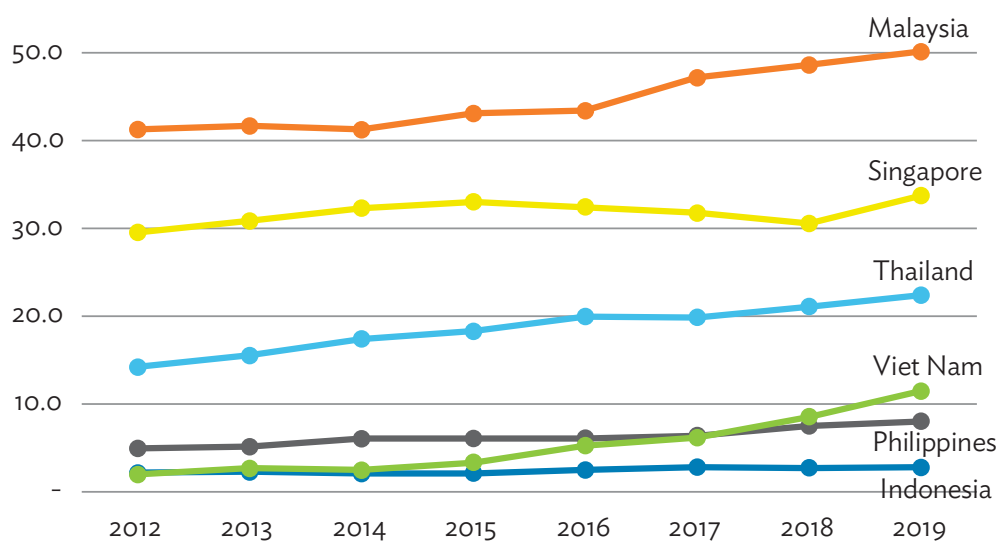

ASEAN = Association of Southeast Asian Nations, GDP = gross domestic product.

Source: Techcombank Securities and Viet Nam Bond Market Association. 
Figure 7: ASEAN Domestic Corporate Bond Issuance

(\$ billion)

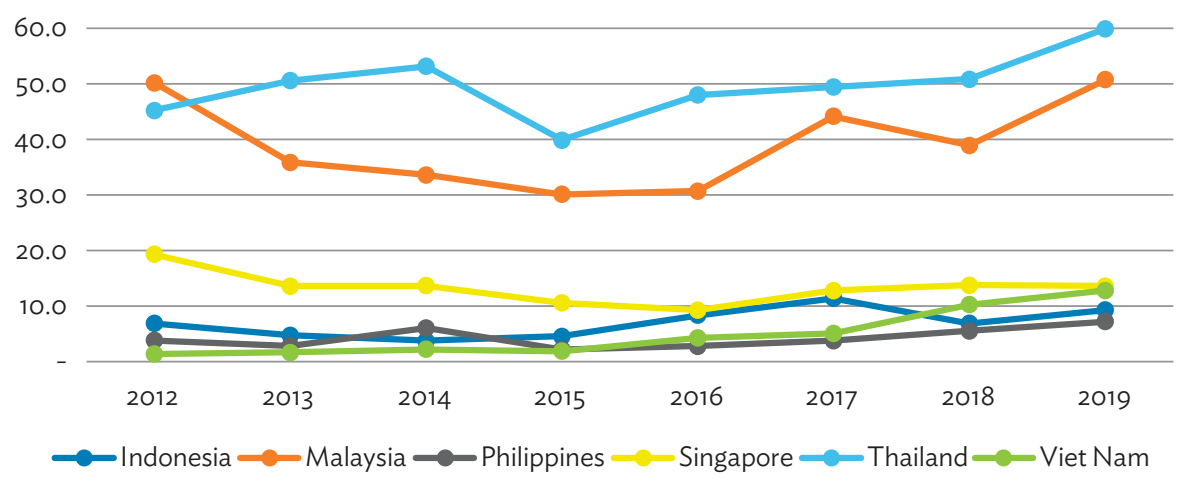

ASEAN $=$ Association of Southeast Asian Nations.

Source: Asian Bonds Onine, Techcombank Securities and Viet Nam Bond Market Association.

45. Thailand overtook Malaysia in 2013 for the highest corporate bond issuance in ASEAN and has remained the leader since then (Figure 7). Viet Nam, which had the lowest corporate bond issuance in 2012, went past the Philippines in 2016 and Indonesia in 2018. It remained at fourth place in 2019 and is now marginally behind third-placed Singapore.

Figire 8: ASEAN Corporate Bonds Outstanding

(\$ billion)

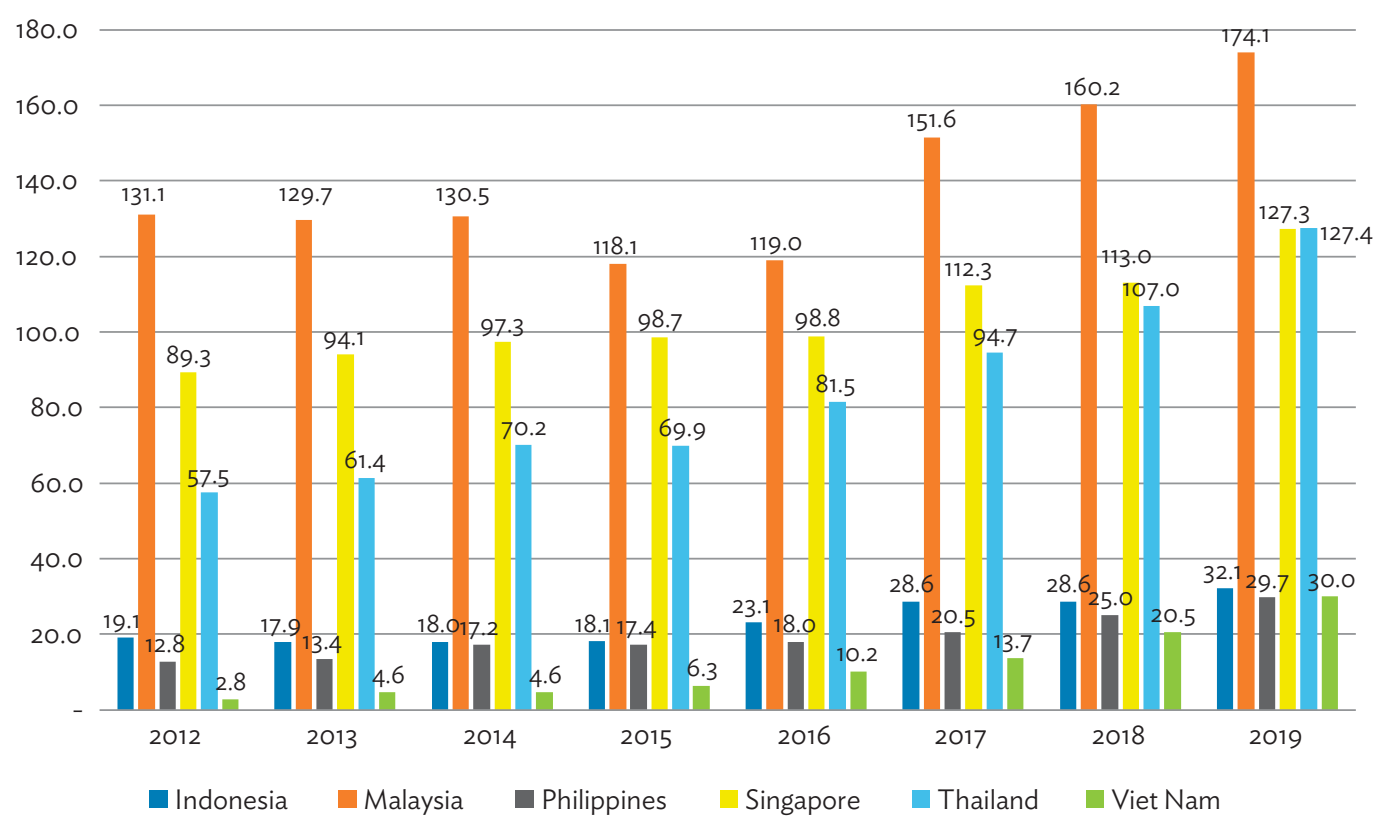

ASEAN = Association of Southeast Asian Nations.

Source: AsianBondsOnine, Techcombank Securities and Ministry of Finance. 
46. Viet Nam's corporate bond issuances grew over nine times since 2012. Its growth of $814 \%$ between 2012 and 2019 was the highest, with the Philippines next at 85\%, and Indonesia at 35\%. Thailand grew 33\% but Singapore declined by 30\% since 2012. Malaysia grew $1 \%$.

47. Viet Nam's aggregate corporate bonds outstanding grew tenfold since 2012 and at the end of 2019 were approximately $\$ 30$ billion, marginally ahead of sixth-placed Philippines (Figure 8). Malaysia leads with the highest volume of corporate bonds outstanding throughout this period. Thailand's corporate bond issuances, even though higher than Malaysia's issuances, have shorter tenors relative to Malaysia where long tenors of over 20 years are not uncommon.

\section{Market Structure}

\section{Issuers}

48. The surge in Viet Nam's corporate bond market has mirrored the country's impressive economic growth. Curbs currently limiting bank credit growth to 14\% per annum (at varying amounts since 2012) for the banking sector as a whole that were imposed by the State Bank of Viet Nam also pushed issuers to the bond market. Issuer reputation and coupon rates have been key drivers for successful completion of bond issues.

49. The easing of requirements for privately placed bond issues provided further impetus for issuance. Privately placed bond issues made up 94\% of total corporate bond issuance in 2019, similar to that of the prior year. These private placements are generally no different in size from public offerings and often exceed D1 trillion (approximately $\$ 43$ million) per issue.

50. Unlike private placements in other countries, which are club deals placed with a handful of institutional investors, private placements in Viet Nam can be sold to a maximum of 99 investors excluding professional investors, or only to professional investors who may include both institutional and individual investors. In Thailand, private placements can be sold to no more than 10 investors; in the Philippines they have to be sold to 19 or fewer investors; in Indonesia, while they could be sold to a maximum of 100 investors, they are usually sold to far fewer than that. Malaysia does not stipulate a maximum number of investors but expects bonds to be sold to a limited or small number of investors in order to be considered private placements. In these four ASEAN markets, public offerings of debt form the bulk of corporate bond issuance and private placements cannot be made to retail investors. Effective June 2020, Indonesia requires all private placements sold to Indonesian investors to be rated; press reports in Thailand suggest that Thailand is likely to announce similar requirements for rating of private placements. In the Philippines and Malaysia, rating of privately placed debt is not mandatory.

51. Although outside ASEAN, it is useful to compare the experience in Viet Nam to India because of the preponderance of privately placed bond issues in both markets. Indian private placements amounted to $\$ 90$ billion during the fiscal year ended 31 March 2020. Private placements of corporate bonds in India have generally exceeded $95 \%$ of total bond issuances every year since 2008; annual issuance of these bonds quadrupled between 2008 and 2020. Indian insurance companies have, in particular, found private placements of corporate bonds to be attractive due to the long-term and fixed nature of their insurance liabilities. Listing regulations, introduced in 2003 in India, require all corporate bonds to be rated. Unrated private placements are rare as institutional investors are constrained by regulation.

52. Banks accounted for $41 \%$ of issuances in Viet Nam in 2019 and real estate companies, 33\%. Banks have been frequent issuers in the bond market, for in addition to financing credit growth they seek capital to build up their capital adequacy ratios beginning from 2019 with the implementation of Basel II. Real estate companies have borrowed aggressively to meet surging demand for properties by buyers. While real estate prices have gone up sharply, these are believed to be still below peaks from the previous 
cycle. The government's anticorruption drive has in the meantime negatively impacted the launch of real estate projects. Overheating in the private placement bond market in 2019 had been causing concern. At least one real estate issuer was known to be under financial stress and had sought assistance from the authorities in Ha Noi.

53. Bond issuances have been an even mix of floating and fixed rates. Fixed rate bonds have coupons in low double digits. Tenors are at the shorter end of the spectrum with banks issuing up to 5 years and corporates up to 3 years. There is hardly any issuance beyond 5 years.

54. The Credit Guarantee \& Investment Facility, an Asian Bond Market initiative, has guaranteed bonds of eight corporate issuers from Viet Nam since 2014. These bonds aggregated D15.7 trillion (\$692 million). Of these, the bonds guaranteed in 2018 amounted to D3.5 trillion ( $\$ 150$ million), and in 2019, D6.0 trillion ( $\$ 260$ million). The Credit Guarantee \& Investment Facility guaranteed bonds were primarily sold to institutional investors from Viet Nam.

55. Banks have been reluctant to provide corporates funding for corporates' medium- to longterm needs, and many of the larger banks have reached single borrower limits for their large corporate borrowers. However, larger issuers from Viet Nam believe that the domestic bond market lacks the depth to meet their large funding needs especially for longer tenors in the 10-to 30-year range.

56. Infrastructure project bonds have not yet developed. This is a priority not just for the growth of the corporate bond market but also to fund infrastructure, a critical development priority. The Public Private Partnership Law passed in June 2020 specifically allows for special purpose vehicles to issue bonds for infrastructure projects.

57. A handful of Vietnamese issuers (a couple of banks, corporates, and sovereign) have issued US dollar bonds offshore. For issuers who have a natural hedge in the US dollar, the offshore bond markets offer a cheaper and more efficient alternative to borrowing in the domestic market.

58. BNP Paribas is the only foreign issuer to have issued dong bonds. Foreign issuers could help accelerate the development of the local bond market and should be pursued.

\section{E. Intermediaries}

59. Techcombank Securities is the largest corporate bond arranger with a 34\% market share. The other market leaders are SSI Securities and VN Direct. Together with other bond arrangers, they are members of the Viet Nam Bond Market Association (VBMA). The VBMA is a not-for-profit industry association comprising mainly bond arrangers and bond investors. It has been instrumental in a number of initiatives to develop and deepen the bond market.

\section{F. Investors}

60. Local investors are few and limited to banks, life insurance companies, and a handful of asset managers with bond funds. Pension and social security funds are conspicuously absent as they are not permitted to invest in nonbank corporate issuers. Viet Nam Social Security, the state-owned pension fund, cannot currently invest in nonbank corporate issuers but can do so in bank bonds. In many other countries, for example Malaysia, state-sponsored pension funds can invest in bonds issued by nonbank corporate issuers with a minimum credit rating and are a key market participant in the development of the corporate bond market. 
61. The life insurance industry has been successful in recent years and has generated significant inflows that ideally should be invested in the local fixed income market. The life insurance companies prefer to invest in sectors with steady predictable cashflows and in companies that have government support. There is a mismatch between the supply and demand for bonds as the supply of bonds has largely been in short tenors, and the life insurance companies have been challenged to find investments to match their long duration liabilities.

62. Foreign investors, mainly individuals, held 5.3\% of corporate bond issuances in 2019, higher than the $0.8 \%$ in the government's bonds. Viet Nam's equity capital markets have been more successful in attracting offshore investors than the bond market. The successful equity issuances in recent years were anchored by offshore investors. But global investors' allocation to Viet Nam fixed income is still relatively very small.

63. Retail investors held $9.6 \%$ of total corporate bond issuance in 2019 , while three-fourths of these issuances were held by banks. There is concern that the risks in the banking sector have not been dispersed as $41 \%$ of all issuance in 2019 was from banks and $75 \%$ of all issuance is held by banks.

64. Secondary market trading is minimal as most investors buy and hold securities for their coupon rates. The lack of a secondary market could hurt retail investors in a declining market especially as they have no access to ongoing credit research.

65. Investors would prefer to see a shift in private placements of bond issues to the public market, which has higher disclosure standards and demands greater regulatory oversight. While the revisions to Decree \#163 in Decree \#81 seek to make that shift, it is uncertain if it will achieve that objective. An effort should be made to further streamline public offerings while tightening standards for private placements. The authorities may also wish to consider the use of medium-term note programs for frequent issuers to market bonds whenever windows of opportunity for fundraising open.

\section{G. Governance and Transparency}

66. The quality of information provided by issuers varies widely. The public listed issuers tend to provide more comprehensive information that enables analysts to build models and cash flow projections. However, issuances from small and medium-sized enterprises (SMEs) tend to provide limited information and pose risks for investors, especially in a declining economic environment.

67. Corporate governance is a work in progress following the code for corporate governance issued in August 2019 by the SSC and the International Finance Corporation. The code is in line with The Organisation for Economic Co-operation and Development principles but is voluntary. When implemented fully, it will bring practices in Viet Nam closer to global best practices. The bigger Vietnamese companies are more likely to be early adopters of the code.

68. The regulatory framework is evolving as Viet Nam embraces international standards. The regulators have routinely introduced laws but enforcement is weak. Decree \#163 has made it easy, according to some investors, for low-quality issuers to place bonds privately. Retail investors looking for yield, relative to bank deposits and treasuries, have often overlooked credit fundamentals and issuers have found it easier to place bonds privately than to secure bank loans.

69. All bond issuances are required to be reported to several agencies upon completion. All bonds should be reported to the Hanoi Stock Exchange or the Ho Chi Minh Stock Exchange, depending upon where the issuer has a listing. Public bond offerings need to be reported to the SSC. Private placements need to be reported to the Ministry of Finance. Banks are required, in addition, to report their issuances to the State Bank of Viet Nam. The VBMA gathers information on issuances provided by the intermediaries. 
The Hanoi Stock Exchange discloses information on issuances on its website. However, information accessible is minimal and not meaningful. The lack of a single point of data collection on issuances has caused confusion on issuance volumes and hinders an accurate assessment of the size of the market.

\section{H. Credit Culture}

70. Market participants are unanimous on the lack of a credit culture, which is seen as one of the biggest risks to the market and is a factor that will inhibit its growth. The credit quality of issuers in Viet Nam is no different from that in other developing countries. The absence of a credible domestic rating agency was a consistent pain point for investors and intermediaries. The rapid increase in private placements and the large exposure of retail, and perhaps unsophisticated, investors is a cause for concern. The need for a domestic credit rating agency is further discussed in Chapter 5.

71. A formal default is not known to have occurred as yet in the corporate bond market. If it did, it would be a test case for the Bankruptcy Law of 2014. Some market participants fear that a default, if it were to occur, could lead to a market collapse. In the view of some others, if an issuer were under duress, the authorities and banks, who would likely hold the largest exposures to the instrument, would come together to find a practical solution and maintain stability in the market.

\section{Bond Market Outlook}

72. Corporate bond issuance during January to May 2020 amounted to D91 trillion ( $\$ 4$ billion) according to data shared by the Ministry of Finance. Issuance activity was up 15\% in 2020 (relative to the same period in 2019) despite the COVID-19 pandemic. Private placements continued their dominance in 2020. Debt issues in 2020 were sold at higher interest rates than in 2019 as banks tightened credit following the COVID-19 crisis and issuers were pushed to raise funds in the bond market. Property firms accounted for $49 \%$ of issuances. Individual investors acquired $23 \%$ of the issuances in 2020 (9.6\% in 2019) attracted by higher coupons relative to bank deposits.

73. Bond issuance for all of 2020 could surpass the issuance level of 2019 , according to a market expert, as property companies seek refinancing of bonds issued in the last few years, and condotels seek funding to plug gaps from sluggish sales of vacation homes. Furthermore, the central bank's limits on banks' credit expansion, and its gradual lowering of limits for banks' use of short-term funds for mediumand long-term loans, will push issuers to raise funds in the bond market.

74. Viet Nam's regulators and policy makers are known to be pragmatic and will bring about any changes necessary to ensure that the bond market's growth path is maintained in the future. Curbs limiting bank credit growth are also likely to push issuers to the domestic bond market for funding their business expansions. The strong issuance levels of Viet Nam's corporate bond market since 2017 should continue and grow in line with the economy, which in turn is underpinned by solid fundamentals.

\section{DOMESTIC CREDIT RATINGS}

\section{A. Background}

75. The urgent need for a domestic rating agency in Viet Nam is clear based on feedback from investors, intermediaries, issuers, and government officials. A credible domestic rating agency is a critical missing jigsaw piece in the orderly development of a healthy sustainable bond market in Viet Nam. 
76. A legal framework for domestic credit ratings was established under Decree \#88 in 2014. As indicated in Chapter 3, under the 2019 Securities Law that will be effective January 2021, some public bond offerings will require a credit rating from a domestic credit rating agency. Despite such efforts by the authorities, demand in the past for a credit rating service has been insufficient to attract the global rating agencies to consider establishing a rating service in Viet Nam.

\section{B. Domestic Rating Agencies}

77. The previous lack of interest from global rating agencies has not, however, prevented domestic investors. VietnamNet Credit Ratings Centre opened in June 2005 as Viet Nam's first credit rating agency. Lack of demand led to its shuttering less than a year later.

78. In July 2017 Phattinh Rating was the first Vietnamese credit rating agency to be licensed under regulations set out in Decree \#88. Based in Ho Chi Minh, Phattinh Rating was founded in 2015 by Phung Xuan Minh, a businessman, together with Saigon Phattinh Investment JSC and Saigon Phattinh Business Consulting Co. Ltd. It has a team of 25 including analysts and members of its credit rating committee. It has rated 30 corporates, financial institutions, and debt instruments (including unsolicited ratings).

79. In March 2020, FiinGroup (formerly known as StoxPlus) became the second credit rating agency to be licensed by the Ministry of Finance. Established in 2008, the group is a data, research, and analytics provider in Viet Nam. The group employs over 100 staff. Banks and asset managers in Viet Nam and some offshore clients subscribe to its platform for accessing corporate research and related reports. In 2019, it issued over 7,000 business reports on SMEs in Viet Nam and has developed an automated credit scoring model, which will be used to determine the credit ratings of SMEs. FiinRating, a sub-brand of FiinGroup, expects to launch its rating service in 2020 with initially an "investor pay" model. Internationally, many rating agencies started with an "investor pay" model, but the trend is to transition to an "issuer pay" model as the market develops.

80. The Ministry of Finance has the authority to grant up to five credit rating licenses. It believes that the rapid growth of the corporate bond market in recent years should attract global rating agencies to establish a Vietnamese operation.

\section{Global Rating Agencies}

81. Although these and potentially other developments among domestic rating agencies are healthy, it is critical that Viet Nam also attract at least one global rating agency. Ratings depend foremost on credibility. If an international rating agency were to partner with a domestic agency, the international rating agency's reputation, corporate governance systems, rating methodologies, and default and loss data could decisively elevate the credibility of the domestic agency.

82. The global credit rating agencies have typically adopted one or more of the following modes of market entry:

(i) technical assistance with no equity interest (India: CRISIL, Indonesia: Pefindo)

(ii) minority equity interest with technical assistance (Malaysia: RAM, Thailand: TRIS and Fitch)

(iii) majority equity interest (Sri Lanka: Fitch)

(iv) wholly owned subsidiary (Indonesia: Fitch, PRC: S\&P Global Ratings PRC) 


\section{Key Success Factors}

83. As global rating agencies survey a potential market, three elements are key:

(i) Analytical independence. An agency should be free from any external pressures whatsoever in determining its credit ratings. External interference will compromise its ratings' quality and lead to an erosion of market reputation.

(ii) Development priority. Policy makers, regulators, and market participants need to be committed to the orderly growth of the bond market. Credit ratings are an integral part of the bond market infrastructure and their usage needs to be supported especially in the bond market's early stages.

(iii) Demand for ratings. Unless there is demand for credit ratings, an agency will not be commercially viable. Even worse, it may compromise on its analytical rigor to survive but with disastrous reputational implications.

84. The following paragraphs discuss each of these key elements.

\section{E. Analytical Independence}

85. The independence of the rating agency is ensured through a governance structure that has checks and balances, clear roles and responsibilities, and robust policies and procedures that protect the integrity of ratings and their analytical rigor. Throughout various interviews, market participants demonstrated a good understanding of the need for a credit rating agency to be independent and free from external interference.

\section{F. Development Priority}

86. Bond defaults of property issuers in the PRC between 2018 and 2019 have convinced authorities in Viet Nam on the critical need for a domestic credit rating agency to help its own market avoid such losses. The authorities are keen to see an orderly growth of a healthy bond market and have a strong commitment toward the bond market and a credit rating agency. There is considerable support from policy makers for private placements of corporate bonds to be voluntarily rated and developing a credit culture. Market participants expressed the same commitment to the growth of the bond market and the development of a credit culture.

87. Many domestic investors indicated that usage of domestic credit ratings in their investment processes would depend upon the global credit rating agencies supporting a domestic entrant.

88. The central bank's caps on bank credit growth are expected to continue for the foreseeable future. As a consequence, issuers are likely to look to domestic bond markets for funding their business expansions.

89. Viet Nam's market participants would prefer to see a collaboration of local institutions with a global rating agency under any of the models outlined in para. 82 . This would lead to an ideal blend of global best practices with a local understanding of culture, businesses, and practices. 


\section{G. Demand for Ratings}

\section{Potential for a Technical Assistance Agreement}

90. With analytical independence and development priority favorable, the key issue is demand for ratings.

91. Viet Nam's corporate bond market, which has grown sharply since 2017, compares favorably with ASEAN neighbors. As indicated in Chapter 4. Viet Nam's corporate bond issuance in 2019 was higher than that of Indonesia and the Philippines. At the end of 2019, its corporate bonds outstanding were for the first time ahead of sixth-ranked Philippines (Figure 9).

Figure 9: Corporate Bonds 2019

(\$ billion)

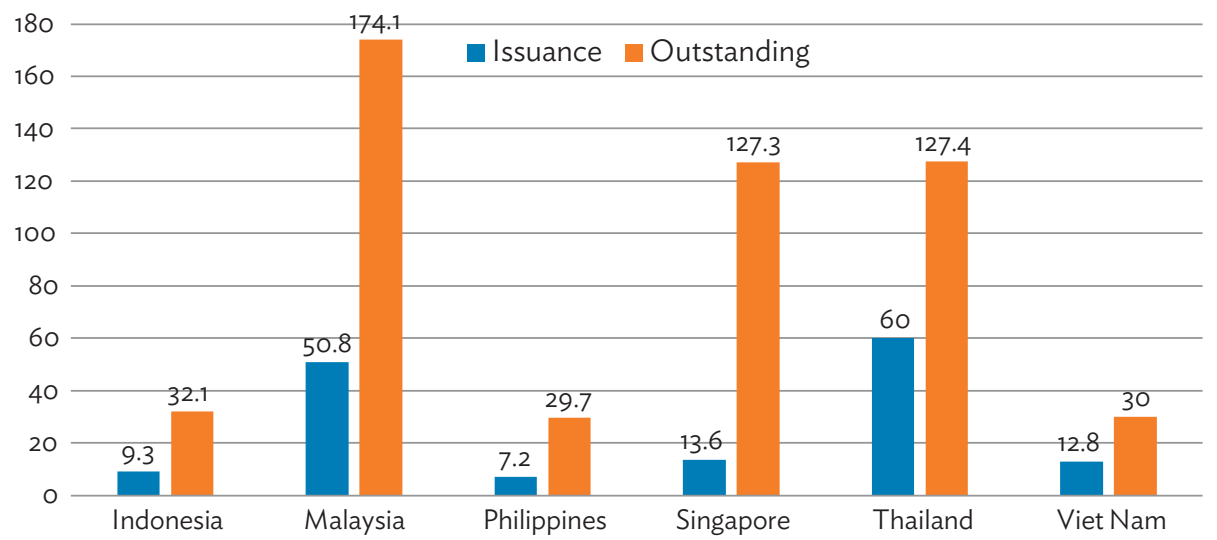

Source: Asian Bonds Online, Techcombank Securities, and Viet Nam Bond Market Association.

92. Moreover, many ASEAN countries have already built successful domestic rating agencies, which in many cases are rating hundreds of entities per annum (Table 2). Their success is supported in part by their technical and strategic partnerships with the global credit rating agencies. These partnerships, which involve the transfer of know-how (rating methodology), have been crucial in helping the domestic venture gain credibility with local market participants. Further, ASEAN's domestic rating agencies have been supported by regulations requiring all bond issues to be rated when these markets first opened. 
Table 2: ASEAN Domestic Ratings Overview

\begin{tabular}{llccc}
\hline Country & \multicolumn{1}{c}{$\begin{array}{c}\text { Domestic Credit Rating } \\
\text { Agencies }\end{array}$} & $\begin{array}{c}\text { Year First CRA } \\
\text { Established }\end{array}$ & $\begin{array}{c}\text { Estimated Number of Rated } \\
\text { Entities }\end{array}$ & $\begin{array}{c}\text { Ratings } \\
\text { Mandatory }\end{array}$ \\
\hline Indonesia & Pefindo, Fitch & 1993 & $>700$ & Yes \\
\hline Malaysia & RAM, MARC & 1990 & $>250$ & No \\
\hline Philippines & Phil Ratings & 1985 & $>75$ & Yes \\
\hline Singapore & Moody's, S\&P, Fitchb & 1995 & $>100$ & No \\
\hline Thailand & TRIS, Fitch & 1993 & $>200$ & Yes \\
\hline Viet Nam & Saigon Phatthinh, Fiin Rating & 2017 & 30 & No \\
\hline
\end{tabular}

ASEAN = Association of Southeast Asian Nations, CRA = credit rating agency.

a Mandatory in Malaysia until 2016.

${ }^{b}$ The global credit rating agencies provide credit ratings for the Singapore domestic market.

Source: Association of Credit Rating Agencies in Asia.

93. Rating demand depends not just on bond ratings but also issuer ratings. Issuer credit ratings are ratings of entities for which the issuer usually pays an annual fee, varying with the complexity of the issuer and the quantum of its bonds outstanding. The issuer rating fees are over and above the bond rating fee, which is charged in the year of issuance and is based on the amount of debt raised.

94. While bond issuance rating fees have sustained many domestic rating agencies in ASEAN in their early years, issuer credit ratings of listed companies, financial institutions, and local governments (municipalities and/or provinces) have helped many of ASEAN's credit rating agencies survive economic and market cycles when bond issuances usually dry up.

95. Table 3 provides a comparison of the potential rating universe for domestic rating agencies in ASEAN. It includes an estimate of the entities currently rated in the region based on information available in the public domain. As with bond ratings, Viet Nam's potential for issuer ratings compares favorably to other ASEAN markets that already have domestic rating agencies.

Table 3: Potential Domestic Credit Rating Universe

\begin{tabular}{lcccccc}
\hline Country & $\begin{array}{c}\text { Listed } \\
\text { Companies }\end{array}$ & $\begin{array}{c}\text { Banks Including } \\
\text { NBFC }\end{array}$ & $\begin{array}{c}\text { Insurance } \\
\text { Companies }\end{array}$ & $\begin{array}{c}\text { Municipal } \\
\text { Entities }\end{array}$ & $\begin{array}{c}\text { Number of Rated } \\
\text { Estimated Entities }\end{array}$ & $\begin{array}{c}\text { Number of } \\
\text { CRA }\end{array}$ \\
\hline Indonesia & 650 & 120 & 135 & 514 & $>700$ & 2 \\
\hline Malaysia & 800 & 45 & 22 & 154 & $>250$ & 2 \\
\hline Philippines & 330 & 600 & 86 & 1,488 & $>75$ & 2 \\
\hline Singapore & 776 & 110 & $>75$ & 16 & $>100$ & 3 \\
\hline Thailand & 770 & 30 & 84 & $>75$ & 7200 & 2 \\
\hline Viet Nam & 400 & 40 & 19 & 63 & 30 & 2 \\
\hline
\end{tabular}

$\mathrm{CRA}=$ credit rating agency, $\mathrm{NBFC}=$ nonbank finance company.

Source: Websites of country stock exchanges, central banks, and Association of Credit Rating Agencies in Asia.

96. Given the potential for bond ratings and issuer ratings, Viet Nam presents an excellent case for a global rating agency to enter the domestic market through a technical assistance agreement. These agreements provide for knowledge transfer of rating methodology and sharing of global and local insights between the partners. The global rating agencies prefer to have a majority shareholding at a mutually 
agreed future date that coincides with the development of the bond market and some maturity in the ratings business. In India; the Republic of Korea; and Taipei,China, the domestic partnerships initially commenced with limited or no shareholdings, but grew to majority interests, as shareholders and market participants became comfortable that the "marriage" was working.

\section{Potential for Equity Investment}

97. The open issue is whether there is sufficient demand for a global agency to invest equity in a local partner. The answer is likely yes. Consider Viet Nam's $\$ 12.8$ billion of issuances in 2019. Assuming a domestic rating agency would charge $0.1 \%$, consistent with fees elsewhere in ASEAN, approximately a third of issuances going forward would need to be rated to generate sufficient revenue to support one domestic rating agency. Although this is achievable, it will take several years based on the experience elsewhere in ASEAN.

98. To develop this credit culture, government, domestic rating agencies, and other stakeholders should pursue three concurrent strategies:

(i) Example of state-owned enterprises. State-owned enterprises are a significant contributor to the Viet Nam economy. They need to raise debt to fund Viet Nam's economic growth, and the government is keen that they borrow against the strength of their own balance sheets. If state-owned enterprises begin to have their issues rated, it will set a normative example to other issuers that ratings are expected.

(ii) Regulatory changes. Demand for credit ratings could be further supported through investment guidelines for investors that allow for a higher allocation of investments in rated bond issues. While these prudential measures are included in the government's Roadmap for the Development of the Bond Market (footnote 3), the incentives to seek credit ratings for bond issues through regulation are by themselves insufficient to create adequate demand for ratings, as noted for Singapore. This is because the supply of bonds by issuers is well below the demand for bonds from investors.

Therefore, consistent with ASEAN's other emerging markets, regulators should require all public offerings of bonds to be rated. The process of streamlining issuance of public bonds should not compromise the requirement to have a rating. Regulations for private placements should be further tightened to shift at least larger issuers and issuances to the public market and for private placements to be the exception rather than the norm. The success stories of Malaysia and Thailand will be hard to replicate in Viet Nam unless the prudential measures adopted by regulators in those markets are also implemented in Viet Nam.

(iii) Market education. Market education can help the market to understand the benefits of ratings. On the one hand, rated issuances tend to be larger and have longer tenors than unrated issuances, and the cost of credit ratings is often recovered in lower borrowing costs. ${ }^{4}$ On the other hand, investors-even those with internal credit rating capacitybenefit from the greater transparency and independent credit analysis that ratings provide. The more that issuers and investors understand these benefits, the quicker the market will transition away from unrated issuances.

\footnotetext{
M. Tuominen. 2014. Credit spread discrepancies between European rated and unrated corporate bonds. Rialto School of Business.
} 
99. If, however, in 2 to 3 years' time issuers remain slow to adopt credit ratings, the government should consider a universal mandate for credit ratings encompassing all publicly and privately listed issuances. While such a requirement will add to transaction costs, it will lead to the development of a credit culture, which is crucial for the development of a vibrant bond market. It is also consistent with international practices. India, which has private placements of corporate bonds on a size and scale like Viet Nam, requires credit ratings for privately placed listed bonds even though these instruments are sold only to institutional investors. The requirement also must not be permanent. Malaysia mandated ratings up until 2016, at which time the credit culture had sufficiently developed to enable the government to relax the requirement. Given that Viet Nam has only recently approved the 2019 Securities Law, it is impracticable to mandate ratings immediately for private placements, but the recommendation is still valid because it signals to the market the importance of changing the credit culture.

\section{Go-to-Market Strategy}

100. A new domestic credit rating agency should spend much of its first 2 years on developing its rating methodology and criteria, building a national rating scale that is calibrated for Viet Nam, educating the market, and analyzing sectors such as banking and real estate. The bulk of bond issuance from 2019 through June 2020 has been from these sectors. The initial focus of the rating agency on these sectors will enable it to serve the needs of market participants while generating revenues to sustain its operations.

101. Signing a technical assistance agreement, whether with or without accompanying equity, with a global credit rating agency will also be a near-term priority to provide the domestic rating agency a head-start on methodology and to give confidence to market participants on the rigor of its analytical processes. Building a sound reputation for analytical excellence in its early years will secure market acceptance and usage of the new firm's credit ratings.

102. Thereafter, new ratings products such as ratings of infrastructure projects (including green bonds) and asset-backed securities could be launched when a regulatory framework has been established for infrastructure project bonds and securitizations of asset pools. Non-rating products and services such as risk analytics, equity indexes, and economic and market research could be added to meet market needs, leveraging the firm's credibility. 


\section{APPENDIX 1: VIET NAM BOND ISSUANCE AND ASEAN DOMESTIC CORPORATE BONDS ISSUANCE AND OUTSTANDING}

TABLE A1.1: Viet Nam Bond Issuance

(\$billion)

\begin{tabular}{|c|c|c|c|c|c|}
\hline Year & Government & Guaranteed & Municipal & Corporate & Total \\
\hline 2012 & 6.8 & 2.5 & 0.2 & 1.4 & 10.9 \\
\hline 2013 & 8.6 & 2.2 & 0.4 & 1.6 & 12.9 \\
\hline 2014 & 11.6 & 1.3 & 0.3 & 2.2 & 15.5 \\
\hline 2015 & 11.4 & 2.1 & 0.3 & 1.9 & 15.8 \\
\hline 2016 & 13.7 & 1.5 & 0.2 & 4.3 & 19.7 \\
\hline 2017 & 10.8 & 1.5 & 0.1 & 5.1 & 17.5 \\
\hline 2018 & 9.5 & 1.1 & 0.0 & 10.3 & 21.0 \\
\hline 2019 & 9.9 & 0.8 & 0.0 & 12.8 & 23.5 \\
\hline
\end{tabular}

Source: Techcombank Securities, and Viet Nam Bond Market Association. Data provided by Techcombank Securities and the Viet Nam Bond Market Association have been used for Vietnamese bonds. Their comprehensive data is preferred over other sources whose estimates, though marginally different, exhibit similar trends.

TABLE A1.2: ASEAN Domestic Corporate Bonds Issuance

(\$ billion)

\begin{tabular}{ccccccccc}
\hline Year & Indonesia & Malaysia & Philippines & Singapore & Thailand & Viet Nam & Total \\
\hline 2012 & 6.9 & 50.2 & 3.9 & 19.4 & 45.2 & 1.4 & 126.9 \\
\hline 2013 & 4.7 & 35.9 & 2.9 & 13.6 & 50.6 & 1.6 & 109.4 \\
\hline 2014 & 3.7 & 33.6 & 6.1 & 13.7 & 53.2 & 2.2 & 112.6 \\
\hline 2015 & 4.5 & 30.2 & 2.2 & 10.6 & 39.9 & 1.9 & 89.3 \\
\hline 2016 & 8.4 & 30.7 & 2.8 & 9.3 & 48.1 & 4.3 & 103.4 \\
\hline 2017 & 11.4 & 44.2 & 3.8 & 12.8 & 49.5 & 5.1 & 126.7 \\
\hline 2018 & 6.9 & 38.9 & 5.5 & 13.7 & 50.9 & 10.3 & 126.2 \\
\hline 2019 & 9.3 & 50.8 & 7.2 & 13.6 & 60.0 & 12.8 & 153.7 \\
\hline
\end{tabular}

ASEAN = Association of Southeast Asian Nations.

Source: Asianbondsonline, Techcombank Securities, and Viet Nam Bond Market Association. 
TABLE A1.3: ASEAN Domestic Corporate Bonds Outstanding (\$billion)

\begin{tabular}{ccccccccc}
\hline Year & Indonesia & Malaysia & Philippines & Singapore & Thailand & Viet Nam & Total \\
\hline 2012 & 19.1 & 131.1 & 12.8 & 89.3 & 57.5 & 2.8 & 312.7 \\
\hline 2013 & 17.9 & 129.7 & 13.4 & 94.1 & 61.4 & 4.6 & 321.1 \\
\hline 2014 & 18.0 & 130.5 & 17.2 & 97.3 & 70.2 & 4.6 & 337.8 \\
\hline 2015 & 18.1 & 118.1 & 17.4 & 98.7 & 69.9 & 6.3 & 328.5 \\
\hline 2016 & 23.1 & 119.0 & 18.0 & 98.8 & 81.5 & 10.2 & 350.6 \\
\hline 2017 & 28.6 & 151.6 & 20.5 & 112.3 & 94.7 & 13.7 & 421.2 \\
\hline 2018 & 28.6 & 160.2 & 25.0 & 113.0 & 107.0 & 20.5 & 454.3 \\
\hline 2019 & 32.1 & 174.1 & 29.7 & 127.3 & 127.4 & 30.0 & 520.6 \\
\hline
\end{tabular}

ASEAN = Association of Southeast Asian Nations.

Source: Asianbondsonline, Techcombank Securities, and Viet Nam Bond Market Association. 


\section{APPENDIX 2: REPORT CONTRIBUTORS}

The following organizations and individuals helped to develop this report's conclusions. They are listed below in alphabetical order.

- AlA Life (Investor)

- Citibank (Foreign bank)

- Dai-ichi Life (Investor)

- FiinRating (Viet Nam credit rating agency)

- Hanoi Stock Exchange (Information aggregator)

- International Finance Corporation (Supranational)

- Military Bank (Issuer and investor)

- Moody's Investor Service (Global credit rating agency)

- PV Power (Issuer)

- Phattinh Rating (Viet Nam credit rating agency)

- S\&P Global Ratings (Global credit rating agency)

- Saigon Securities Investment Company (Intermediary)

- SHB Bank (Saigon Hanoi Bank - issuer and investor)

- SSI Asset Management (Investor)

- SSI Securities (Intermediary)

- State Bank of Viet Nam (Central Bank)

- State Securities Commission of Viet Nam (Regulator)

- SunLife (Investor)

- Techcombank Securities (Intermediary)

- Vientinbank (Issuer and investor)

- Vietcombank (Issuer and investor)

- Viet Nam Bond Market Association (Association of intermediaries and investors)

- Viet Nam Social Security (Investor-state-owned pension fund)

- VN Direct (Intermediary)

- VP Bank Securities (Intermediary)

- Warut Promboon (Consultant that worked on an early version of this report) 


\section{The Potential for Foreign Investment in a Domestic Credit Rating Agency in Viet Nam}

This report evaluates the attractiveness of the Viet Nam bond market from a global credit rating agency's perspective. It concludes that the business case for an international rating agency to enter the Vietnamese market through a technical service agreement is compelling. Moreover, Viet Nam already issues relatively more corporate debt than countries such as Indonesia and the Philippines. The more these bonds are rated -either through changes in the credit culture or regulations - the clearer the case will be for an international rating agency to go beyond a technical agreement and invest equity in a domestic credit rating agency.

\section{About the Asian Development Bank}

ADB is committed to achieving a prosperous, inclusive, resilient, and sustainable Asia and the Pacific, while sustaining its efforts to eradicate extreme poverty. Established in 1966, it is owned by 68 members -49 from the region. Its main instruments for helping its developing member countries are policy dialogue, loans, equity investments, guarantees, grants, and technical assistance. 